\title{
PELATIHAN PERBAIKAN DAN PERAWATAN AIR CONDITIONER (AC)
}

\author{
Imam Arif Rahardjo ${ }^{1}$ \\ Fakultas Teknik Fakultas Ekonomi Universitas Negeri Jakarta
}

\begin{abstract}
ABSTRAK
Pelatihan Perbaikan Dan Perawatan Air Conditioner (AC). Pelatihan ini bertujuan untuk memberikan pengetahuan dan ketrampilan perbaikan dan perawatan Air Conditoner kepada TKI yang sudah kembali ke Indonesia sehingga mendapatkan bekal yang positif. Pelaksanaan pelatihan perbaikan dan perawatan Air Conditioner dilaksanakan di TUK SMKN 26 Jakarta. Pelatihan dibagi dalam 2 (dua) sesi, yaitu sesi teori, dan sesi praktik. Pada sesi pertama peserta diberikan pengetahuan terkait dengan teori berupa materi - materi penunjang praktik. Materi disampaikan dengan metode ceramah, dan diskusi/tanya jawab. Dan pada sesi kedua peserta diberikan ketrampilan praktik terkait pencucian unit AC (pembersihan indoor dan outdoor) dan pengecekan performa AC. Materi disampaikan dengan metode demontrasi/ peragaan dan praktik yang diikuti oleh peserta. Kesimpulan dari pelatihan ini adalah peserta pelatihan peduli dan antusias terhadap materi pelatihan pelatihan perbaikan dan perawatan Air Conditioner, peserta pelatihan sangat berperan aktif dalam kegiatan pelatihan perbaikan dan perawatan Air Conditioner, peserta pelatihan sebagian besar dapat memahami materi yang diajarkan meskipun materi yang diajarkan merupakan hal yang baru, peserta pelatihan memiliki pengetahuan terkait perbaikan dan perawatan Air Conditioner, peserta pelatihan memiliki ketrampilan berkaitan perbaikan dan perawatan Air Conditioner.
\end{abstract}

Kata kunci : Pelatihan, Perbaikan, Perawatan, Air Conditioner (AC)

\section{PENDAHULUAN}

\section{A. LATAR BELAKANG}

Permasalahan pertama yang melatarbelakangi pengusulah pelatihan ini adalah berkaitan dengan Tenaga Keja Indonesia (TKI). TKI menjadi salah satu penyumbang devisa negara dengan jumlah transfer uang mencapai US\$ 7,05 miliar per tahun. Besarnya penyebab tingginya tingkat keinginan sebagian warga negara Indonesia menjadi TKI, adalah pendapatan yang lebih besar dari negara sendiri dengan tingkat skill yang sama. Umumnya para TKI adalah para pekerja dengan tingkat skill yang rendah. Sehingga sekembalinya ke Indonesia, meskipun memiliki uang yang lebih banyak karena skillnya yang rendah maka para TKI akan lebih cenderung kembali menjadi TKI dari pada bekerja di negara sendiri. Padahal dampak psikologi keluarga yang di tinggalkan tentu tidak sebanding dengan pendapatannya di negeri orang, apalagi dkaitkan dengan pembangunan manusia secara keseluruhan.

Permasalahan kedua adalah kecenderungan masyarakat Indonesia untuk berwirausaha yang masih relatif sangat rendah. Penyebab utama rendahnya keinginan untuk berwirausaha adalah berkaitan dengan modal. Sehingga meskipun memiliki skill yang sudah tinggi, masyarakat lebih cenderung memilih bekerja dari pada berwirausaha.

Permasalah ketiga adalah meningkatnya penggunaan pendingin udara (Air Conditioner). Di Indonesia, penggunanaan pendingin udara (Air Conditioner) mengalami peningkatan yang cukup pesat, khususnya di kota-kota besar. Hal ini dikarenakan suhu udara yang semakin meningkat, sehingga dibutuhkan suatu peralatan untuk menurunkan suhu udara ruangan guna memperoleh kenyamanan yang diinginkan. Banyaknya pemakaian sistem pendingin berpengaruh pula dalam perbaikan dan perawatannya. Sehingga diperlukan banyak tenaga ahli untuk melakukan perbaikan dan perawatan pada peralatan tersebut. Perbaikan dan perawatan sangatlah perlu dilakukan untuk memperpanjang umur peralatan. Apabila salah satu sistem perangkat tersebut tidak berfungsi dengan baik,

\footnotetext{
${ }^{1}$ Dosen Program Studi Pendidikan Teknik Elektro Universitas Negeri Jakarta
} 
maka dapat menyebabkan peralatan tersebut tidak efektif dan efisien.

Berdasarkan ketiga permalahan di atas, memberikan ketertarikan untuk membuat pelatihan Perbaikan dan Perawatan Air Conditioner kepada para TKI yang sudah kembali ke Indonesia untuk berwirausaha. Pelatihan ini ditujukan untk meningkatkan skill TKI. Selanjutnya TKI yang telah memiliki skill yang meningkat dan juga selaku pemilik modal, maka sekiranya dapat berwirausaha. Sehingga manfaat yang dapat diperoleh bagi para TKI dengan berwirausaha yaitu tidak perlu kembali ke negeri orang untuk kembali bekerja. Selanjutnya lapangan pekerjaan tentunya juga akan semakin meningkat.

\section{B. PERUMUSAN MASALAH}

Berdasarkan rasional maka dapat diidentifikasikan masalah sebagai berikut: "Bagaimana memberikan pelatihan perbaikan dan perawatan Air Conditoner?"

\section{TUJUAN}

Adapun pelatihan ini bertujuan untuk memberikan pengetahuan dan ketrampilan perbaikan dan perawatan Air Conditoner kepada TKI yang sudah kembali ke Indonesia sehingga mendapatkan bekal yang positif

\section{MANFAAT KEGIATAN}

Setelah kegiatan pelatihan ini maka dapat diuraikan manfaat yang nyata, yaitu sebagai berikut :

1. Peserta mengetahui tentang perawatan Air Conditoner.

2. Peserta mengetahui prosedur perbaikan Air Conditoner dengan baik dan benar.

3. Peserta memiliki ketrampilan melakukan per baikan dan perawatan Air Conditoner.

\section{TEMPAT DAN WAKTU PELATIHAN}

\section{Tempat}

Pelaksanaan pelatihan perbaikan dan perawatan Air Conditioner dilaksanakan di TUK SMKN 26 Jakarta

\section{Waktu}

Pelaksanaan pelatihan perbaikan dan perawatan Air Conditioner dilaksanakan pada tanggal 31 Agustus 2016.

\section{TAHAP PELATIHAN}

Kegiatan pelatihan dibagi dalam 2 (dua) sesi, yaitu sesi teori, dan sesi praktik. Adapun rincian hasil pelatihan sebagai berikut :

\section{A. SESI PERTAMA}

Pada sesi pertama peserta diberikan pengetahuan terkait dengan teori berupa materi - materi penunjang praktik. Materi disampaikan dengan metode ceramah, dan diskusi/tanya jawab.

\section{B. SESI KEDUA}

Pada sesi kedua peserta diberikan ketrampilan praktik terkait pencucian unit AC (pembersihan indoor dan outdoor) dan pengecekan performa AC. Materi disampaikan dengan metode demontrasi/peragaan dan praktik yang diikuti oleh peserta.

\section{HASIL PELATIHAN}

Berdasarkan hasil pelatihan selama 2 sesi diperoleh beberapa hasil yang tercapai saat pelaksanaan $\mathrm{P} 2 \mathrm{M}$, antara lain :

1) Peserta pelatihan peduli dan antusias terhadap materi pelatihan pelatihan perbaikan dan perawatan Air Conditioner.

2) Peserta pelatihan sangat berperan aktif dalam kegiatan pelatihan perbaikan dan perawatan Air Conditioner.

3) Peserta pelatihan sebagian besar dapat memahami materi yang diajarkan meskipun materi yang diajarkan merupakan hal yang baru

4) Peserta pelatihan memiliki pengetahuan terkait perbaikan dan perawatan Air Conditioner.

5) Peserta pelatihan memiliki ketrampilan berkaitan perbaikan dan perawatan Air Conditioner

\section{KESIMPULAN}

Beberapa kesimpulan yang diperoleh melalui kegiatan Penelitan dan Pengabdian Kepada 
Masyarakat (P2M) adalah sebagai berikut:

1. Kegiatan pelatihan perbaikan dan perawatan Air Conditioner telah dilakukan di TUK SMKN 26 dengan jumlah peserta 15 orang.

2. Dalam rangka optimalisasi pelatihan perbaikan dan perawatan Air Conditioner, maka kegiatan pelatihan dibagi dalam 2 (dua) sesi, yaitu sesi teori, dan sesi praktik

3. Antusias dan motivasi yang tinggi dari peserta pelatihan perbaikan dan perawatan Air Conditioner

4. Menambah pengetahuan dan ketrampilan peserta pelatihan perbaikan dan perawatan Air Conditioner.

5. Salah satu Tri Darma Perguruan Tinggi adalah Pengabdian pada Masyarakat sangatlah positif untuk mengaplikasikan pengetahuan praktis kepada masyarakat.

\section{SARAN}

Mengingat salah satu Tri darma Perguruan Tinggi, maka sudah sepatutnya Universitas Negeri Jakarta bekerja sama dengan Dinas terkait untuk kegiatan - kegiatan Pengabdian Pada Masyarakat. Sehingga tindak lanjut dari kegiatan pelatihan dapat dioptimalkan sehingga kompetensi peserta dapat tersertifikasi maupun dapat dibina sehingga dapat membuka usaha kecil menengah

\section{DAFTAR PUSTAKA}

Air Conditioning \& Refrigerasi Sanken, Jakarta : Departemen Service Jakarta

Job sheet AC Split SMK Negeri 54 Jakarta, Jakarta: Pusat Program Keahlian Teknik Pendingin dan Tata Udara

Rahardjo Imam Arif (2010), "Pembuatan Video Pembelajaran Prosedur Pemeliharaan Peralatan Tata Udara Ruang Tinggal (Room Air Conditioner/ RAC)”, Skripsi : FT UNJ. 